\title{
A targeted public: public services in fifteenth-century Ghent and Bruges
}

\author{
JELLE HAEMERS ${ }^{\dagger}$ and WOUTER RYCKBOSCH ${ }^{\ddagger *}$ \\ $\dagger$ Vakgroep Middeleeuwse Geschiedenis, Universiteit Gent, Blandijnberg 2, \\ 9000 Gent, Belgium \\ $\ddagger$ Dept Geschiedenis, Universiteit Antwerpen, Stadscampus, S.R.A11, \\ Rodestraat 14, 2000 Antwerpen, Belgium
}

\begin{abstract}
Though the phrase 'public services' is a nineteenth-century invention, which was supported by a developed rhetoric of political economy, this article shows that the concept, practice and supply of such services could also be found in the medieval city. It specifically analyses three areas of urban service provision: jurisprudence and legal security, infrastructure and finally health care and poor relief. Although the available sources tend to stress the involvement of municipal authorities in providing public services, it turns out that in fact the furnishing of services was highly multi-layered. In all three areas studied, a wide range of public and private institutions offered services to specific groups within late medieval urban society. In contrast to what the notion of 'public services' lets us presume, however, public services in the medieval city were not available to all inhabitants. Instead, the provision of services was usually quite restrictive, and targeted particular groups in society.
\end{abstract}

The allocation of public services in late medieval towns was as multilayered as urban society itself. Because not only the urban government, but also the court, the church and voluntary associations of citizens could organize public services in the medieval cities, both the provision of public services and people's eligibility to use those services were highly fragmented and multi-layered in the medieval city. Several institutions provided comparable services within the same geographical area. For example, a survey of welfare provision (one of the hallmarks of the city as Caroline Barron has called it) in late medieval London shows that this relief was secured by a series of measures, of which some were provided by the city corporately, some by religious houses, some by fraternities and

\footnotetext{
* The research for this article was financed by the IAP-project (VI, 32) 'City and society in the Low Countries, 1100-1800' of the Federal Science Policy of Belgium and by the Research Foundation of Flanders (FWO). We want to thank Shennan Hutton, Christian Liddy, Manon van der Heijden, Peter Stabel and Griet Vermeesch for their comments on a first version of this article, which was presented at the Ninth European Urban History Conference in Lyon (30 Aug. 2008).
} 
companies and many by charitable individuals working through these institutions, or even independently. ${ }^{1}$ Urban infrastructure works could also be highly fragmented. A study of the building policies in late medieval Italian cities, for instance, revealed that several institutions, such as the church, the municipal authorities, the duke or count, as well as private burghers invested in market squares, official buildings, etc. ${ }^{2}$ This dispersed supply and scattered usage of public services was typical for the medieval city because it was a corporate society. The social fabric of medieval towns consisted of diverse and overlapping layers of social identities, solidarities, networks and institutions. Corporate bodies, neighbourhoods, religious institutions and political and institutional organizations gave structure to this complex urban society. No single authority centralized the allocation of public services, because the origins, structure and operations of the services were different. Yet we claim that each service had a different target; each service aimed at a different public.

First, however, the use of the notion of 'public services' needs clarification. Although it has conceptual roots in the Age of the Enlightenment and the French Revolution, the notion of 'public services' is a nineteenth-century invention. In his Wealth of Nations, Adam Smith (1723-90) dedicated a chapter to 'Public works and institutions for facilitating the commerce of the society'. ${ }^{3}$ He argued that a government had to stimulate economic wealth by supplying useful public works projects. He contrasted this kind of initiative with the economic policy of a despotic 'Ancien' regime, which considered only the private benefit of the court and the leading nobility. Project initiatives could be carried out by a private company, but they were to be financed by the public government. Inspired by the 'enlightened' revolutions at the end of the eighteenth century, nineteenth-century liberals built on Smith's ideas by introducing 'public services' into politics. To the liberals, the legal concept of 'public services' meant projects to improve the country's infrastructure in support of the economic sector. The funding of these 'public' works by the state was legitimized by the notion of 'general interest': every subject of the state could use the public infrastructure, and the economic surplus value of the investments was in the interest of all. ${ }^{4}$ Nineteenth-century socialist and communist ideologies made social investments the core concern of

${ }^{1}$ C. Barron, London in the Later Middle Ages. Government and People, 1200-1500 (Oxford, 2004), 301.

2 E. Crouzet-Pavan, Les villes vivantes. Italie, XIIIe-XVe siècle (Paris, 2009), 131-59.

3 A. Smith, An Inquiry into the Nature and Causes of the Wealth of Nations (Edinburgh, 1776), ed. A. Krueger (New York, 2003), ch. 1 of book V. See also A. Skinner, The Market and the State. Essays in Honour of Adam Smith (Oxford, 1976); F. Démier, 'Economistes libéraux et "services publics" dans la France du premier XIXe siècle', Revue d'histoire moderne et contemporaine, 52 (2005), 34-6.

4 D. Margairaz, 'L'invention du "service public": entre "changement matériel" et "contrainte de nommer"', Revue d'histoire moderne et contemporaine, 52 (2005), 15; P. Jourdan, 'La formation du concept de service public', Revue du droit public, 103 (1987), 89-118. 
the 'public services' of the state or municipal authorities. ${ }^{5}$ By investing in social security systems and the supply of energy, water and other utilities, the state and cities demonstrated they cared not only for the 'wealth of nations' but also for the 'wealth of people'. As a result, present-day states provide a broad range of public services, although some of them were privatized due to neo-liberal tendencies in the second half of the twentieth century. ${ }^{6}$

In spite of its nineteenth-century roots, the notion of 'public services' can be a useful tool for studying medieval society. For this article argues that a public initiative did exist in the medieval city as well, even though the concept of 'public services' was not present in medieval law or politics. Therefore we have to clarify what we mean by the notion of 'public' and explore in what ways it can be applied in a medieval context. In a brilliant essay, Jeff Weintraub distinguishes several ways in which the term 'public' is currently defined in social and political analysis. ${ }^{7}$ Two of them are the point of departure for this article, which considers public services as political initiatives carried out with the aim of providing a certain facility that could be used by people. Adam Smith, for instance, defines public services as an initiative of a governmental body. Medieval municipal distribution systems (for water supply, health care and so on) count as 'public services' according to this understanding, since they were the result of legitimate coercion and authoritative direction by the city administration. In line with this definition, services provided by the church, crown or medieval court can also be regarded as public initiatives, because these institutions possessed coercive power in medieval society.

A second understanding of the concept 'public' views the 'public' realm in terms of political community and citizenship: at the heart of 'public life' is a process of active participation in collective decision-making, carried out within a framework of fundamental solidarity and equality. From this point of view, the medieval city was a 'public' realm, because it was governed by participatory self-determination, deliberation and conscious co-operation among equals, namely among those who had citizenship rights. If we use this notion of 'public', services supplied by urban craft guilds (or comparable organizations in the city, such as confraternities or labour organizations), and even private initiatives, can be regarded

${ }^{5}$ See, for example, R. Colls and R. Rodger (eds.), Cities of Ideas: Civil Society and Urban Governance in Britain, 1800-2000 (Aldershot, 2004); M. Dagenais, I. Maver and P.-Y. Saunier (eds.), Municipal Services and Employees in the Modern City: New Historic Approaches (Aldershot, 2003); C. Kleinschmidt, 'Services urbains en Allemagne: l'économie municipale d'approvisionnement entre industrialisation et reconversion', Histoire, economie et société, 26 (2007), 101-10; S. Gunn, 'Governance, citizenship, and municipal provision in the modern city', Journal of Urban History, 33 (2007), 1006-14.

${ }^{6}$ P. Chambat, 'Service public et néolibéralisme', Annales. Économies, sociétés, civilisations, 45 (1990), 615-47.

$7 \mathrm{~J}$. Weintraub, 'The theory and politics of the public/private distinction', in idem and K. Kumar (eds.), Public and Private in Thought and Practice. Perspectives on a Grand Dichotomy (Chicago, 1997), 1-42. 
as public services. Contractually created organizations of human beings who act and deliberate in concert, such as craft guilds in the medieval city, were self-governing and therefore constituted public institutions. Membership of a craft guild - much like citizenship - entailed participation in a particular kind of community: one marked by, among other things, privileges, fundamental (internal) political equality and consideration and resolution of public issues through conscious collective decisionmaking. Craft guilds, or other groups of citizens acting in concert, could provide services (such as health care), either for their members, or for fellow citizens. An individual initiative of a citizen who by himself established a hospital in town can also be considered as a public service. A private initiative can offer a certain facility for a large community, which sometimes had to pay for it. The financial requirement imposed on the user did not render the service less 'public', for we argue that every public service had legal, social or financial restrictions for its users. Neither does the fact that the provider extracted profits from a service prevent us from labelling it a 'public service', for we argue that every public service had a particular goal - political legitimacy, economic gain or (group or individual) profits. This is at least what our inquiry into the late medieval cities of Ghent and Bruges demonstrates.

\section{Municipal provision of public services in late medieval Ghent and Bruges}

Although the zenith of their economic and political power had passed, the cities of Ghent and Bruges were by the fifteenth century still the leading urban players in the Low Countries. In contrast to most other European urban centres outside of Italy, they were already highly developed demographically and economically speaking from the twelfth and thirteenth centuries onwards. This early legacy still had a strong influence on the institutions, power relations and public services present in the cities during the fifteenth century. At the same time, both cities serve as excellent examples of important industrial and commercial centres within the wider European context. Economically, the industrial city of Ghent went through a transition phase in which its focus gradually shifted from large-scale, export-oriented textile production to growing regional trade and production. The city added to its cloth manufacturing a flourishing trade in grain and other foodstuffs, taking advantage of its location at the confluence of two important rivers. ${ }^{8} \mathrm{~A}$ mix of industrial and commercial business, the presence of Italian merchants and a great Hanseatic office made Bruges the international gateway to the Flemish

${ }^{8}$ M. Howell and M. Boone, 'Becoming early modern in the late medieval Low Countries. Ghent and Douai from the fourteenth to the sixteenth century', Urban History, 23 (1996), 300-24; D. Nicholas, The Metamorphosis of a Medieval City. Ghent in the Age of the Arteveldes, 1302-1390 (Lincoln, NB, 1987). 
economy. Although the city of Antwerp would surpass Bruges as the most important port and trading centre in north-western Europe at the end of the fifteenth century, the city was still dominant in the 1400s. ${ }^{9}$ Few cities in Europe north of the Alps were as populous as Ghent, with 45,000 to 50,000 inhabitants, and Bruges, with 40,000 to $45,000{ }^{10}$ Both cities were quasi-autonomous political units within the county of Flanders and dominated the surrounding countryside. The fifteenth century was, however, characterized by a gradual expansion of the power of the count of Flanders. Certainly after the dynastic shift of 1384 (when the dukes of Burgundy became counts of Flanders) there were many clashes between Bruges and Ghent on the one side and the growing state on the other. ${ }^{11}$ But these clashes did not diminish the cities as powerful political actors in the county, nor did they reduce the ability of urban elites to invest in public facilities. Given their scale and their economic importance, these cities form an excellent case-study for an investigation of the provision and the practice of public services in medieval society.

The accounts of the city magistrates of Bruges and Ghent are the only historical sources which provide us with detailed quantitative data about public services in these cities. A short analysis of the Ghent city accounts sheds some light on the political choices and priorities of the city government in providing public services. On average, the annual expenditure on all public services during the fifteenth century amounted to 21.2 per cent of total spending. We have divided these into four categories (Table 1). The largest share of spending on public services, 7.7 per cent, was taken up by the expenses for public works and infrastructure. Figure 1 makes clear that the expenses for public works were highly volatile and subject to considerable variation. This fluctuation can be explained by the periodic nature of building projects. ${ }^{12}$ An almost identical portion of the budget was spent on the salaries of the city personnel, such as the aldermen, the town clerks and the small police force. The costs for justice and administration were quite diverse, including payments to aldermen

9 J. Murray, Bruges, Cradle of Capitalism, 1280-1390 (Cambridge, 2005); J. Bolton and F. Bruscoli, 'When did Antwerp replace Bruges as the commercial and financial centre of north-western Europe? The evidence of the Borromei ledger for 1438', Economic History Review, 61 (2008), 360-79.

10 W. Prevenier, 'La démographie des villes du comté de Flandre aux XIVe et XVe siècles. État de la question. Essai d'interprétation', Revue du Nord, 65 (1983), 255-75; J. Dumolyn, 'Population et structures professionnelles à Bruges aux XIVe et XVe siècles', Revue du Nord, 81 (1999), 43-64.

11 W. Blockmans and W. Prevenier, The Promised Lands: The Low Countries under Burgundian Rule, 1369-1530 (Philadelphia, 1999); J. Dumolyn and J. Haemers, 'Patterns of urban rebellion in medieval Flanders', Journal of Medieval History, 31 (2005), 369-93.

12 Infrastructure projects could sometimes have a serious impact on urban budgets. Between 1400 and 1405 , the city of Bruges, for example, spent an average of 25.5 to $38.2 \%$ of its annual budget on public works, while Damme spent $49 \%$ in 1431-34; see J.-P. Sosson, 'A propos des "travaux publics" de quelques villes de Flandre aux XIVe et XVe siècles: impact budgétaire, importance relative des investissements, technostructures, politiques économiques', in Het openbaar initiatief van de gemeenten in België. Historische grondslagen (Ancien Régime) (Brussels, 1984), 381. 
Table 1: Average expenses for municipal services, Ghent (fifteenth century)

\begin{tabular}{lcc}
\hline \hline & & $\begin{array}{l}\text { Per cent of } \\
\text { annual } \\
\text { expenditure }\end{array}$ \\
\hline Alms and charity & In d.gr.Fl. & $\begin{array}{l}\text { expenditure type } \\
\text { Justice and administration }\end{array}$ \\
Public works and infrastructure & 73,712 & 4.1 \\
Wages (and 'clothing') & 139,331 & 7.7 \\
Total public services & 133,597 & 7.3 \\
\hline
\end{tabular}

Source: City Archives Ghent, series 400 (City Accounts), 14011500. The table shows the common currency in medieval Flanders, the so-called groot (d.gr.), or Flemish penny.

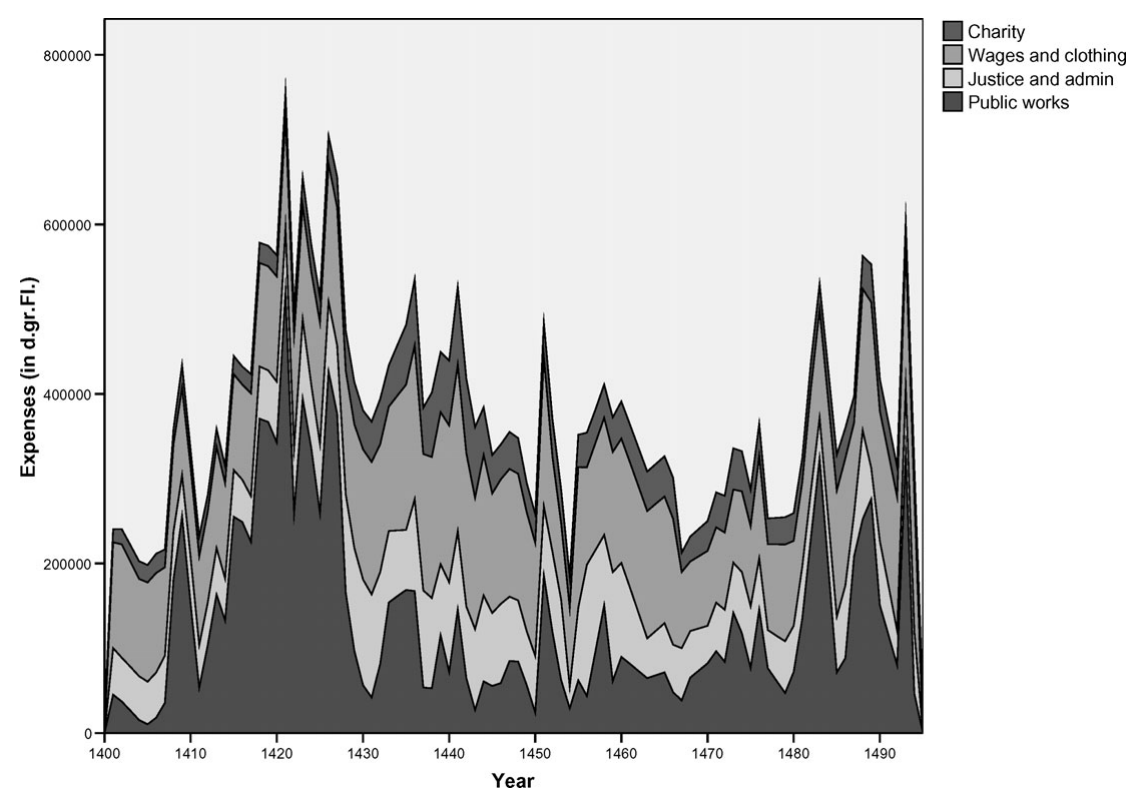

Figure 1: Expenditure on municipal service provision in fifteenth-century Ghent

as judges, expenses for the fire brigade and costs incurred for the annual reappointment of the boards of magistrates. Finally, a very modest share (2.1 per cent) went to alms and charity.

Regarding the long-term evolution of municipal spending on public services, the data reveal several patterns. First, Figure 2 clearly demonstrates that the money spent on public services remained fairly 


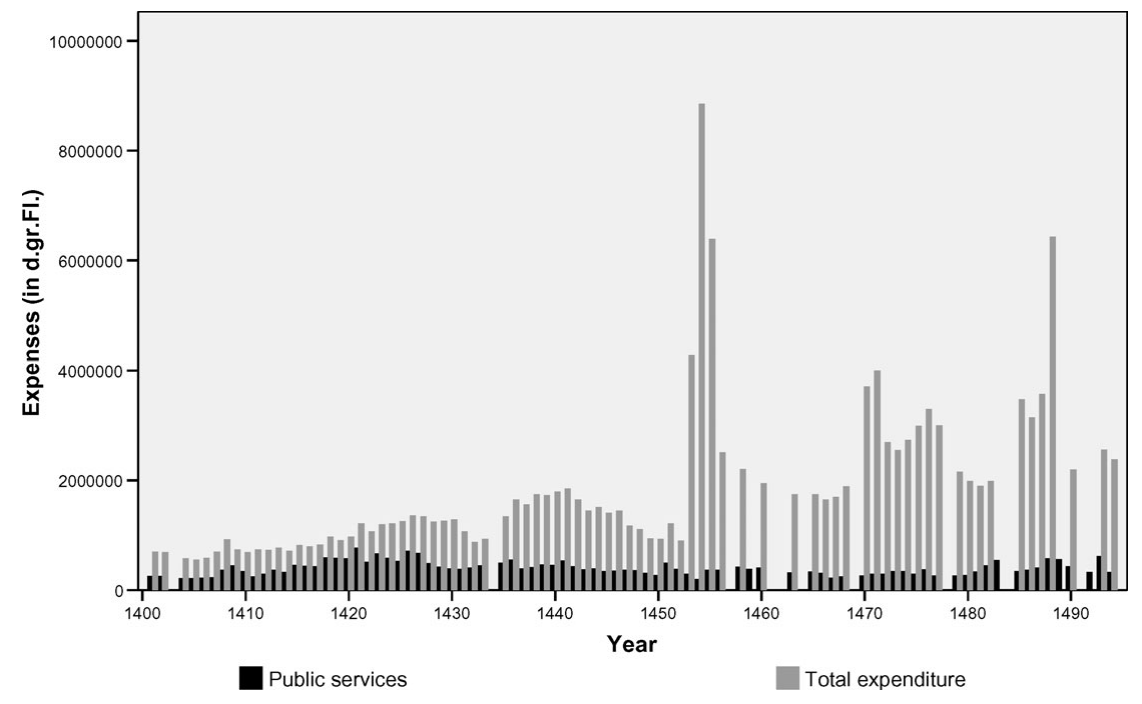

Figure 2: Expenditure on municipal services in fifteenth-century Ghent

stable over the course of the fifteenth century in comparison to the spectacular increase in expenses as a whole during the second half of the century. The general increase of urban revenues did not, therefore, occasion greater spending on public services. There were only temporary increases in expenses, for ambitious building projects or food aid in times of shortage. Some noticeable short-term changes were also due to political decisions, such as the decline in wage expenses in 1468 (Figure 1), when after the Ghent revolt of that same year the so-called 'Ducal Restriction' discontinued payments to the aldermen. ${ }^{13}$ In short, investing significantly in public services was not an issue on the urban politicians' agenda. The city spent limited amounts of money on the administration of law, provision of food aid and on occasional infrastructure projects, but larger investments in public services did not occur. The data from the Ghent accounts seem to indicate that urban politicians had other political priorities in mind.

Finally, it is worth inquiring how the municipal services provided by the city were financed. Throughout the fifteenth century, the lion's share of the total annual revenues of the city of Ghent came from indirect taxation, namely excise taxes on grain, beer, peat and wine (which raised on average

${ }^{13}$ M. Boone, 'Législation communale et ingérence princière: la "restriction" de Charles le Téméraire pour la ville de Gand (13 juillet 1468)', in J.-M. Cauchies and E. Bousmar (eds.), 'Faire bans, edictz et statuz'. Légiférer dans la ville médiévale. Sources, objets, acteurs de l'activité législative communale en Occident, ca. 1200-1500 (Brussels, 2001), 142-6. 
65 per cent of the city's total revenues).${ }^{14}$ Because all consumers in the city (citizens and passing visitors alike - except for members of the clergy and the count's household, who were excluded) had to pay these taxes, all contributed to the provision of municipal services. In exchange for his financial outlay, the tax-payer could use urban infrastructure and rely on a certain degree of legal security in town. He or she could not, however, make use of all the municipal services, because legal and social restrictions limited the number of services to which he could have access. But membership in the 'community of tax-payers' still gave citizens and visitors the right to enjoy minimal services provided by the city. Therefore, we can also view taxation as a criterion for access to certain public services, although it was not the only one. In the following outline of public services provided by the various actors in civil society, we will again show that legal and social restrictions applied to those who wished to use public services. For this purpose, we have distinguished three main areas of activity: jurisprudence and legal security, public works and infrastructure and finally social provisions, such as poor relief and health care.

\section{Jurisprudence and legal security}

We first turn to the service at the heart of the institutional history of the town governments of Ghent and Bruges: the judicial power of the aldermen. Since the town aldermen were first judges and then legislators, their judicial activity was their most important task. ${ }^{15}$ They operated in at least two distinct fields: penal law, and the recording of civil contracts which means the formal recognition of the validity of all kinds of judicial acts that were brought by citizens before the aldermen, on payment of a certain sum. The first task of the aldermen can be considered as a public service in the sense that it was supposed to guarantee personal and public safety, and to ensure public order and the observance of law and authority. The aldermen had jurisdiction over any conflicts involving a citizen of the town, as well as over all cases originating within the city's geographical boundaries. Yet, the judicial services of the city extended well beyond its own boundaries, since the so-called buitenpoorters ('foreign burghers') - individuals who lived outside the city, but who had purchased citizenship - enjoyed the right to be judged by the aldermen. ${ }^{16}$ The second task of the aldermen established a certain level of legal security in town.

${ }^{14} \mathrm{M}$. Boone, Geld en macht. De Gentse stadsfinanciën en de Bourgondische staatsvorming, 13841453 (Ghent, 1990), 123-5; W. Ryckbosch, Tussen Gavere en Cadzand. De Gentse stadsfinanciën op het einde van de Middeleeuwen, 1460-1495 (Ghent, 2006), 127-32.

15 J. Decavele, 'Bestuursinstellingen van de stad Gent (einde $11^{\text {de }}$ eeuw-1795)', and J. Mertens, 'Bestuursinstellingen van de stad Brugge (1127-1795)', in W. Prevenier and B. Augustyn (eds.), De gewestelijke en lokale overheidsinstellingen in Vlaanderen tot 1795 (Brussels, 1997), respectively 277-320, and 323-32.

${ }^{16}$ M. Boone, 'Droit de bourgeoisie et particularisme urbain dans la Flandre bourguignonne et habsbourgeoise (1384-1585)', Revue belge de philologie et d'histoire, 74 (1996), 707-26. 
As governors of the city, the aldermen were responsible for witnessing and sealing written contracts between citizens, both men and women, only after they had paid for this service. ${ }^{17}$ The registration of judicial acts supported mutual trust between buyers and sellers, or creditors and debtors. In Ghent both city benches (the Keure and Gedele - the latter only dealt with orphan affairs), and in Bruges the so-called klerken van de vierschare, had the authority to register legal agreements and contracts. This service was restricted judicially to Ghent citizens only. Since they had to pay for the registration, we can presume that it also was socially limited. ${ }^{18}$

On a much smaller scale, courts in each parish (vinders in Ghent, deelmannen in Bruges) were charged with resolving small-scale conflicts between citizens. ${ }^{19}$ Since its members were appointed by the town magistrates themselves and often included former aldermen who were in between two political offices, we can consider the vinders as a subdivision of the aldermen's courts. This judicial office was locally based and only authorized to take on conflicts over inheritance or private violence. However, the extent of their activity is difficult to reconstruct because their registers have not survived. An important task of the vinders was the registration of so-called zoendingen. These were private peace settlements which had been concluded between inhabitants of the city without any judgment by the urban magistracy. ${ }^{20}$ This practice was widespread in late medieval Ghent and Bruges. Its success shows the judicial power of the urban magistracy was limited in practice, because citizens first tried to resolve their conflicts by themselves. ${ }^{21}$ Nicholas estimated that only 10 per cent of all judicial conflicts in fourteenth-century Ghent was resolved by the full judicial process before the aldermen. ${ }^{22}$

17 See the studies of S. Hutton, "'On herself and all her property": women's economic activities in late medieval Ghent', Continuity and Change, 20 (2005), 325-49; and D. Nicholas, 'The governance of fourteenth-century Ghent: the theory and practice of public administration', in B. Bachrach and D. Nicholas (eds.), Law, Custom, and the Social Fabric in Medieval Europe (Kalamazoo, 1990), 235-60.

${ }_{18}$ M. Boone, 'Openbare diensten en initiatieven te Gent tijdens de Late Middeleeuwen (14de15de eeuw)', in Het openbaar initiatief, 78-80; A. Schouteet, De klerken van de vierschaar te Brugge met inventaris van hun protocollen bewaard op het Brugse Stadsarchief (Bruges, 1973).

19 A. Gheldolf, Les coutumes de la ville de Gand (Brussels, 1868), 408-12; Decavele, 'Bestuursinstellingen van de stad Gent', 300; Mertens, 'Bestuursinstellingen van de stad Brugge', 325.

${ }^{20}$ H. Van Hamme, 'Stedelijk particularisme versus vorstelijke centralisatie en hun impact op de bestraffing van de criminaliteit in het vijftiende-eeuwse Gent (ca. 1419 - ca. 1480)', Handelingen van de Maatschappij voor Geschiedenis en Oudheidkunde te Gent (HMGOG), 55 (2001), 135-78; E. Strubbe and A. Schouteet, 'Over het zoending te Brugge na 1542', Handelingen van het Genootschap voor Geschiedenis 'Société d'Emulation de Bruges', 87 (1950), 5-92; X. Rousseaux, 'Entre accomodement local et contrôle étatique. Pratiques judiciaires et non-judiciaires dans le règlement des conflits en Europe médiévale et moderne', in B. Garnot and R. Fry (eds.), L'infrajudiciaire du Moyen Âge à l'époque contemporaine (Dijon, 1996), 95.

${ }^{21}$ F. Buylaert, 'Familiekwesties. De beheersing van vetes en private conflicten in de elite van het laatmiddeleeuwse Gent', Stadsgeschiedenis, 2 (2007), 1-19.

22 D. Nicholas, 'Crime and punishment in fourteenth-century Ghent', Revue belge de philologie et d'histoire, 48 (1970), 314. 
The aldermen and the lower law courts were thus not the only institutions administering justice in late medieval Ghent and Bruges. Citizens of Ghent could also rely on the judicial services of the so-called viri heriditarii (erfachtighe lieden, literally: 'hereditary men'), who also enjoyed the privilege of validating legal acts. This group largely consisted of powerful families of landholders who lived off their investments. They maintained a monopoly on rule of the city before the social revolt of 1302 , in which the craft guilds obtained the right to participate in urban government. ${ }^{23}$ Originally, the 'hereditary men' witnessed oral agreements among their fellow townsmen, but by the thirteenth century, these agreements were often written. All that was required of the witnesses was their presence and their seals affixed to the final document. Although the involvement of the viri heriditarii in voluntary jurisprudence in Ghent rapidly diminished during the fourteenth century, there is some evidence that they were still active in this area well into the fifteenth century. ${ }^{24}$ It is noteworthy in this respect that there was a division of labour between the aldermen and viri heriditarii which ran parallel to a social division among those who wanted to validate their acts and transactions. Whereas the clergy and the wealthy elite of the town (the poorterij), who belonged to the hereditary families which provided the service, mainly turned to the viri, other citizens who could afford the expense seem to have relied on the judicial power of the aldermen. ${ }^{25}$ The different institutions therefore served different publics. After the craft guilds had gained a political role in the city, in the form of permanent representation on the city boards, during the fourteenth century, the authority of those boards grew. As a result, a new wealthy group of powerful families emerged from the upper crust of the artisans. They did not belong to the hereditary lineages, and therefore they made use of the judicial services of the aldermen, some of whom they elected each year.

The representative of the count of Flanders, the bailiff (baljuw) in Ghent, and the sheriff in Bruges (schout), also upheld law in the cities. They were the political representatives of the count in the city, but they could also act as a public prosecutor in order to maintain civic order. ${ }^{26}$ Their importance as public prosecutors was however rather limited in practice, because the bailiff and sheriff mainly served as a type of judge for cases of 'composition' (compositie). Composition took place when the accused party in a conflict agreed to pay a certain sum to the accuser(s) and the bailiff or sheriff, in exchange for the latter not pressing charges in a full court procedure.

${ }^{23}$ Dumolyn and Haemers, 'Patterns of urban rebellion', 374-7.

${ }^{24} \mathrm{Ph}$. Lardinois, 'Symptomen van een middeleeuwse clan: de erfachtige lieden te Gent in de eerste helft van de $14^{\text {de }}$ eeuw', HMGOG, 31 (1977), 72-6; A. Nevejans, 'Aldus staet in scepenen bouc...De registers van de Gentse schepenen van de Keure in de $14^{\text {de }}$ eeuw', HMGOG, 56 (2002), 53-64. The viri did not exist in Bruges.

${ }^{25}$ Lardinois, 'Symptomen van een middeleeuwse clan', 75-6.

${ }^{26} \mathrm{~J}$. Van Rompaey, Het grafelijk baljuwsambt in Vlaanderen tijdens de Boergondische periode (Brussels, 1967), 271-8. 
Such compositions could take place before the bailiff or sheriff, but also before the town aldermen. This was a widespread judicial practice in the late medieval cities of Flanders, which underscores the conclusion that the judicial power of the urban aldermen was limited in Ghent and Bruges. ${ }^{27}$ Citizens and (moneyed) inhabitants of the city settled conflicts themselves or with the help of the ducal representative, without the interference of the urban magistracy.

Although craft guilds in the Low Countries regularly relied on the city magistrates for the formal proclamation of their corporate rules, a large number of conflicts that arose within those corporate structures were resolved by the guild deans and law courts. Only when serious problems arose between separate guilds, or when the deans were not able to achieve viable resolution of a conflict, did procedures before the aldermen courts begin. But mainly, as in most cities in Western Europe, craft guilds engaged in semi-autonomous regulation, arbitration, enforcement of control and sanctions. ${ }^{28}$ Violence between craftsmen, conflicts between craft guilds or violations of guild privileges were resolved and judged by the government of the craft guilds. The dean and his vinders (the administrative advisors in the craft guild) had the right to pronounce sentences and approve settlements reached through arbitration and negotiation. This legal service, of course, was limited to guild members, although they were allowed to accuse and charge non-members before the guild government.

Finally, (supra-local) ecclesiastical jurisdiction made sure canon law was observed in Bruges and Ghent. Both cities came under the consistory court of the bishop of Tournai. ${ }^{29}$ Ghent and Bruges were also seats of the local court of the deacon of Christianity, which was essentially a lower court for the bishop. These ecclesiastical courts judged clerics charged with crimes, but also had authority to judge laymen. However, Tournai was not in the county of Flanders, but fell instead under the direct control of the king of France. Consequently, the judicial influence of the bishop of Tournai was rather limited inside the cities of Bruges and Ghent. Only for violations of canon law, such as marital law, did the consistory court of Tournai intervene directly in civil affairs. Lay citizens of Ghent or Bruges could originally file a legal suit against fellow laymen in the consistory court of Tournai for opportunistic reasons. The dukes of Burgundy and the Flemish

27 J. Van Rompaey, 'Het compositierecht in Vlaanderen van de veertiende tot de achttiende eeuw', Revue d'histoire du droit, 29 (1961), 43-79; Nicholas, 'Crime and punishment', 290; R. Van Caenegem, Geschiedenis van het strafprocesrecht in Vlaanderen van de XIe tot de XIVe eeuw (Brussels, 1956), 57-9.

${ }^{28} \mathrm{M}$. Boone, 'Les gens de métiers à l'époque corporative à Gand et les litiges professionels (1350-1450)', in M. Boone and M. Prak (eds.), Individual, Corporate and Judicial Status in European Cities, Late Middle Ages and Early Modern Period (Leuven, 1996), 23-47; P. Stabel, 'Guilds in late medieval Flanders: myths and realities of guild life in an export-oriented environment', Journal of Medieval History, 30 (2004), 187-212.

${ }^{29} \mathrm{M}$. Vleeschouwers-Van Melkebeek, 'Marital breakdown before the consistory courts of Brussels, Cambrai, and Tournai: judicial separation a mensa et thoro', Revue d'histoire $d u$ droit, 72 (2004), 81-9. 
cities took concerted action to dispute this regularly, and forbade it outright in 1486. ${ }^{30}$ Finally, in Bruges several 'juridical isles' existed, such as the so-called Proosse, in which only the chapter house of the Saint Donatian church had juridical authority. In these clearly demarcated geographical areas within the city, they took over the tasks of the aldermen and the sheriff. ${ }^{31}$

This brief overview of judicial 'management' of the city clearly shows that no single provider of judicial services enjoyed a monopolistic position at the local level. ${ }^{32}$ Conflict management and the provision of judicial 'services' in Bruges and Ghent were in fact very diverse and highly fragmented. Nor could everyone profit equally from these services. Every legal provider had its specific clientele and 'target'. Those who did not have citizen rights were excluded from municipal services. The financial threshold for achieving citizenship (both for those who lived inside or outside the city) also marked social boundaries which determined who could use these services. The fact that several thousand non-residents bought their way into this entitlement attests to the potential benefits of belonging to the in-group of citizens. As far as voluntary jurisdiction is concerned (and the resulting legal security for economic transactions), it follows from the nature of these transactions that mostly the wealthy and prosperous elites reaped the benefit from these services.

\section{Urban infrastructure}

Urban public infrastructure projects potentially serve many collective purposes. In Adam Smith's view, they mainly promote economic activity by facilitating transport (i.e. ports, roads, canals, gates, cranes, etc.) or by organizing and enhancing places where goods are exchanged (i.e. market places, belfries, trading halls, etc.). Apart from this purely economic function, public works can serve the urbanization process itself (i.e. by expanding city walls or constructing new roads), improve public health, enhance defence and enable the exploitation of natural resources - to name just a few common functions. In fifteenth-century Bruges and Ghent, although there was no single provider of public works who performed all these functions, city government was clearly the most important public

${ }^{30}$ M. Vleeschouwers-Van Melkebeek, 'L'officialité de Tournai aux prises avec les juridictions séculières au XVe siècle: un lent effritement', in M. Maillard-Luypaert and J.-M. Cauchies (eds.), De Pise à Trente: la réforme de l'Église en gestation. Regards croisés entre Escaut et Meuse (Brussels, 2004), 231-54.

31 L. Gilliodts-Van Severen, Coutume de la prevote de Bruges (Brussels, 1878), vol. I, 1.

32 Furthermore, we did not even include notaries, or the Bruges procedure of 'arbitration' (arbitrage). 'Arbitration' happened when an intermediary specialist in trade law judged disputes between merchants. Flemish notaries were the primary intermediaries between church courts and laymen, but 'they did not succeed in becoming anymore than that', according to J. Murray, 'Failure of corporation: notaries public in medieval Bruges', Journal of Medieval History, 12 (1986), 164; see also H. Callewier, 'Brugge, 15de-eeuwse centrum van het notariaat in de Nederlanden', Tijdschrift voor Rechtsgeschiedenis, 67 (2009), 74-102. 
works supplier. Throughout the fifteenth century, the aldermen in Ghent spent an annual average of 7.7 per cent of their total funds on public works and infrastructure. ${ }^{33}$ Between 1400 and 1500, an average of 7.5 per cent of the annual spending by the city of Bruges went to the construction or restoration of urban infrastructure. ${ }^{34}$ This budget paid for repairs and maintenance of existing infrastructure, as well as for the construction of new bridges, ports, dikes or buildings. Because the city accounts of Bruges and Ghent offer special insight into the management of public works, it is tempting to see the city government as the only initiator of this type of 'public service'. The role of the magistrates and the public character of this service, however, need to be carefully scrutinized.

The first complication is that the municipal government was not the only body undertaking construction projects in the cities. During the fourteenth century most of the craft guilds in Ghent and Bruges had erected guild halls for meetings of their members, storing archives and housing the guild leadership. ${ }^{35}$ Like religious institutions, craft guilds also founded hospitals in Bruges and Ghent. The dukes of Burgundy invested in ambitious building programmes in both cities, although their structures were for private use. ${ }^{36}$ Often neighbourhoods played an important role in channelling both the demand for public works projects and the realization of this demand. The municipal accounts reveal that the town magistrates sometimes shared the financial burden of an investment in public infrastructure with the neighbourhood concerned usually following the initiative of the neighbourhood itself. Boone, for example, mentions a Ghent bridge-restoration project which was financed by a joint venture between the surrounding neighbourhood and the urban government. Occasionally, neighbourhoods even financed and carried out infrastructure projects on their own. ${ }^{37}$ Due to the nature of the sources available, the precise scale of neighbourhood activity remains difficult to discern. Flemish sources do not mention individuals leaving money in wills for repairing or building bridges, as was a common practice in English cities, such as London. ${ }^{38}$ However, the involvement of neighbourhoods in the building policy of towns suggests that the aldermen did not monopolize public works, nor did they always respond adequately to neighbourhood demands.

Secondly, although some of these infrastructure projects, such as roads, ports or market places, could be used by everyone, some groups

33 Boone, Geld en macht, table 16; Ryckbosch, Tussen Gavere en Cadzand, 326.

34 J.-P. Sosson, Les travaux publics de la ville de Bruges (XIVe-XVe siècles). Les travaux. Les hommes (Brussels, 1977), graph 22.

35 J. Dambruyne, 'Corporative capital and social representation in the Southern and Northern Netherlands, 1500-1800', in M. Prak et al. (eds.), Craft Guilds in the Early Modern Low Countries. Work, Power and Representation (Aldershot, 2006), 195-7.

${ }^{36} \mathrm{~K}$. De Jonge, 'Bourgondische residenties in het graafschap Vlaanderen. Rijsel, Brugge en Gent ten tijde van Filips de Goede', HMGOG, 54 (2000), 93-134.

37 Boone, Geld en macht, 107-8.

38 Barron, London in the Late Middle Ages, 50-1. 
managed to benefit from them more than others. Investments in economic infrastructure may have been of some benefit to the majority of the urban population at some point, but they were usually in the direct interest of a small number of powerful economic elites. During the fourteenth century a complex network of halls and markets was constructed in Bruges and Ghent to create an optimal infrastructure for international trade, the basis of the wealth of both cities. These building projects, which largely shaped the modern vista of the historic city centres of both towns, were mainly undertaken by city governments which included the craft guilds. Before that time, urban space was still private property held by old families, such as the viri heriditarii in Ghent, since the twelfth century. But when the craft guilds gained a measure of power in the cities, the city government undertook ambitious building projects and constructed market places on land which would now be available for use by everyone. Sometimes the commodities themselves dictated the organization of market places, but there were other important forces at work as well, such as the social and corporate organization of the urban economy and the political equilibrium between the guilds and the merchants. ${ }^{39}$ The Flemish craft guilds used the political power that they had gained at the beginning of the fourteenth century to reorganize urban infrastructure and create a beneficial economic space for corporate organizations. Typical examples of their projects were the construction of market squares and wool halls, as well as the meat hall in Ghent, and the crane for unloading ships in Bruges. In both cities, huge new market squares were laid out during the fourteenth century as sites for the craft guilds to sell their goods (the Vrijdagmarkt in Ghent, and the Grote Markt in Bruges). Medieval market squares were, of course, not only economic spaces, but also served as excellent settings for political gatherings and cultural ceremonies of the craft guilds and other social groups. ${ }^{40}$ While these infrastructure projects undoubtedly stimulated the urban economy as a whole, by far the greatest benefit was to the craft guilds and the merchant elites. ${ }^{41}$ Therefore, we may conclude that building projects targeted specific urban groups.

${ }^{39}$ P. Stabel, 'From the market to the shop. Retail and urban space in late medieval Bruges', in B. Blondé et al. (eds.), Buyers and Sellers. Retail Circuits and Practices in Medieval and Early Modern Europe (Turnhout, 2006), 79-108.

${ }^{40} \mathrm{~J}$. Masschaele, 'The public space of the marketplace in medieval England', Speculum, 77 (2002), 383-421; M.C. Laleman, 'Espaces publiques dans les villes flamandes au Moyen Âge: l'apport de l'archéologie urbaine', in M. Boone and P. Stabel (eds.), Shaping Urban Identity in Late Medieval Europe (Leuven, 2000), 25-41; E. Lecuppre-Desjardin, 'Multipolarité et multifonctionnalité des places publiques dans les villes des anciens Pays-Bas bourguignons: évolution d'une géographie identitaire (XIVe-XVIe siècles)', in L. Baudoux-Rousseau, Y. Carbonnier and P. Bragard (eds.), La place publique urbaine $d u$ Moyen Âge à nos jours (Arras, 2007), 45-52; M. Boone and H. Porfyriou, 'Markets, squares, streets: urban space, a tool for cultural exchange', in D. Calabi and S. Christensen (eds.), Cultural Exchange in Early Modern Europe, vol. II: Cities and Cultural Exchange in Europe, 1400-1700 (Cambridge, 2007), 227-53.

${ }^{41}$ P. Stabel, 'Public or private, collective or individual? The spaces of late medieval trade in the Low Countries', in D. Calabi and S. Beltramo (eds.), Il mercante patrizio. Palazzi e botteghe nell'Europa del Rinascimento (Turin, 2008), 43-8. 
Some infrastructure projects even performed a direct political legitimization role for the ruling groups in city government. These types of prestigious building projects seem to have been fairly common during the fifteenth century, as the following example illustrates. After the revolt of the Flemish cities in 1477 against the autocratic policies of Duke Charles the Bold, the magistrates of Bruges and Ghent made large investments in symbols of urban autonomy erected in stone. ${ }^{42}$ In these revolts both cities regained privileges of political autonomy which they had lost in the previous years. The restoration of urban autonomy clearly inspired the governments of Bruges and Ghent to embellish the main symbols of their urban identity with prestigious building projects. In Ghent, the magistrates spent a sizeable proportion of their budget on a brand-new town hall. In Bruges, an octagonal tower was erected on top of the original square tower of the Belfry, where the town's charters were kept. The town also invested in the restoration of the adjacent cloth halls, which the craft guilds used for commerce in wool, spices and cloth. ${ }^{43}$ These prestigious projects were designed to convince citizens of the legitimacy of urban autonomy and the political position of the town's elite in its conflict with the Burgundian dynasty. The construction of the giant market squares in fourteenth-century Bruges and Ghent had later political implications. These market squares also provided a political forum for the craft guilds to gather their members and, in times of need, to mobilize military forces to defend the city. ${ }^{44}$ The (political) advantages of these municipal projects clearly benefited the ruling regime and their supporters, the merchant elite and the craft guilds.

There was another, more concrete way for certain groups to profit from municipal investment in public works. Prosopographical analysis for Ghent and Bruges has shown that the subcontractors who built the majority of the infrastructure projects largely belonged to the same group of financial, corporate, and political elites. ${ }^{45}$ Moreover, this lucrative subcontracting and supply of building materials were real incubators for corruption, as the substantial accusations of misuse of municipal funds in Ghent in 1451-52 and in Bruges in 1477 reveal. ${ }^{46}$ Although corruption and

42 J. Haemers, For the Common Good. State Power and Urban Revolts in the Reign of Mary of Burgundy, 1477-1482 (Turnhout, 2009), 203-5; Ryckbosch, Tussen Gavere en Cadzand, 94-6.

43 A. Janssens, 'Het Brugse belfort. Wisselend uitzicht tussen omstreeks 1480 en 1503', Brugs Ommeland, 44 (2004), 67-84; J. Haemers and E. Lecuppre-Desjardin, 'Conquérir et reconquérir l'espace urbain. Le triomphe de la collectivité sur l'individu dans le cadre de la révolte brugeoise de 1488', in C. Deligne and C. Billen (eds.), Voisinages, coexistences, appropriations. Groupes sociaux et territoires urbains du Moyen Âge au $16^{e}$ siècle (Turnhout, 2007), 119-43.

44 P. Arnade, 'Crowds, banners and the market place: symbols of defiance and defeat during the Ghent War of 1452-1453', Journal of Medieval and Renaissance Studies, 24 (1994), 47197; M. Boone, 'Urban space and political conflict in late medieval Flanders', Journal of Interdisciplinary History, 32 (2002), 621-40.

45 Sosson, 'A propos des "travaux publics"', 388; Boone, Geld en macht, 103-8.

46 J. Haemers, De Gentse opstand (1449-1453). De strijd tussen rivaliserende netwerken om het stedelijke kapitaal (Kortrijk, 2004), 211-12; A. Janssens, 'Macht en onmacht van de Brugse schepenbank in de periode 1477-1490', Handelingen van het Genootschap voor Geschiedenis 'Société d'Emulation de Bruges', 133 (1996), 5-45. 
nepotism were widespread in medieval politics, the main reason that the power holders invested in urban infrastructure clearly cannot be sought in these excesses of power. Like most urban governments in the Low Countries, the magistrates of Bruges and Ghent made the ideological claim that their building programmes primarily served 'the common good' of the city. ${ }^{47}$ But, as Pierre Bourdieu observes, ideologies which claim to strive for 'the common good' in fact try to present private or group interests as the interests of all. ${ }^{48}$ Even though the municipal works carried out by the city did often serve a broad community, they principally benefited the financial and political elite in several direct and indirect ways. In comparison to those large-scale projects which primarily benefited a small minority of the population, the projects which involved the active participation of neighbourhoods seem to have been more modest and more in tune with the actual need for infrastructure work.

\section{Health care and poor relief}

In Ghent and Bruges poor relief and health care were organized by different corporate bodies, for different people. Like most cities and towns of any size in medieval Europe, they featured a wide variety of institutions devoted to the assistance of people defined in some way as 'poor' ${ }^{49}$ The supply of services for the poor was very fragmented, because the clergy, the count, the craft guilds, the urban government and wealthy citizens had all established forms of poor relief in Ghent and Bruges. Obviously, the ecclesiastical institutions played a considerable role in providing poor relief, but as we shall see, the church did not monopolize the distribution of goods to the have-nots of society. In Ghent, for example, St Peter's Abbey distributed money, clothes and food to the poor on holy days. This provision was rather symbolic in nature and was less than one year's wages for a bricklayer in the first decade of the fifteenth century. ${ }^{50}$ Some of the religious institutions in medieval Bruges and Ghent also provided health care, responding to a spiritual ideal as much as to a social need..$^{51}$ There were, for example, hospitals run by beguines in Bruges and Ghent. These religious communities of laywomen lived isolated in court beguinages in the cities - there were three court beguinages in Ghent, and one in Bruges.

${ }^{47}$ E. Lecuppre-Desjardin, 'Des pouvoirs inscrits dans la pierre? Essai sur l'édilité urbaine dans les anciens Pays-Bas bourguignons', Memini. Travaux et documents publiés par la Société des études médiévales du Québec, 7 (2003), 29.

48 P. Bourdieu, Language and Symbolic Power (Cambridge, 1991), 167-9.

${ }^{49}$ M. Mollat, Les pauvres au Moyen Âge. Étude sociale (Paris, 1978); B. Geremek, Poverty: A History (Oxford, 1994); C. Lis and H. Soly, Poverty and Capitalism in Pre-Industrial Europe (London, 1979).

50 W. Blockmans and W. Prevenier, 'Armoede in de Nederlanden van de 14e tot het midden van de 16e eeuw: bronnen en problemen', Tijdschrift voor Geschiedenis, 88 (1975), 573-4.

${ }^{51}$ For example the hospital of St Ann, founded by the abbey of St Bavo in Ghent (Acht eeuwen Gentse ziekenhuizen (Ghent, 1993), 35). 
The beguine hospitals originally cared for a small group of poor people (a maximum of 25 inmates), without any sort of 'social selection' taking place. But as we will note for the civic hospitals in Ghent and Bruges, by the fourteenth and certainly by the fifteenth century clerics had a tendency to reserve charitable care for a select public. This select public was mainly composed of the religious community that had established the hospital, and their (mostly wealthy) relatives (who could buy themselves a bed in the hospital). ${ }^{52}$

For his personal salvation, but also for his prestige and political authority, the count of Flanders gave financial aid to religious institutions, hospitals and individual poor people in the Flemish cities. In the fifteenth century the count of Flanders (after 1384 the duke of Burgundy) spent an average of 0.25 per cent of his revenues on poor relief. This voluntary assistance was, however, very restricted in time, monetary value and number of beneficiaries. ${ }^{53}$ While religious institutions and hospitals regularly received donations from the court, individual paupers only received money when the count of Flanders resided in the city. Every year between 25 and 50 people received a financial gift, food or goods from the 'receiver of the alms' of the count (receveur de l'aulmosnerie). This poor relief was therefore quite marginal and not structural at all. It was inspired by a paternalistic view of society, religious motives and political intentions. Although symbolically important, the distribution of (minor) gifts by the count seems to have been quite inefficient from a social relief perspective, since the central state did not take the trouble to find out who needed assistance and who did not.

In contrast to this occasional support from the count, the poor relief provided by the urban 'Holy Spirit Tables' (Heilige Geesttafels) was more fundamental. These parish institutions run by lay people, unique to the Low Countries and Catalonia, were responsible for the care of the so-called 'shame-faced house-poor' (scamele huuslieden). ${ }^{54}$ The revenue sources of the poor tables were diverse, but most of the funds came from private benefactors. For the salvation of their souls, wealthy citizens gave annuities, land, real estate or sums of money during their lifetimes or

52 W. Simons, Cities of Ladies: Beguine Communities in the Medieval Low Countries, 1200-1565 (Philadelphia, 2003), 77; O. Nübel, Mittelalterliche Beginen- und Sozialsiedlungen in den Niederlanden. Ein Beitrag zur Vorgeschichte der Fuggerei (Tübingen, 1970), 173-80.

53 W. Prevenier, 'En marge de l'assistance aux pauvres: l'aumonerie des comtes de Flandres et des ducs de Bourgogne (13 - début $16^{\mathrm{e}}$ siècle)', in Recht en instellingen in de Oude Nederlanden tijdens de Middeleeuwen en de Nieuwe Tijden. Liber amicorum Jan Buntinx (Leuven, 1981), 97-138.

54 M.-J. Tits-Dieuaide, 'Les tables des pauvres dans les anciennes principautés belges au Moyen Âge', Tijdschrift voor Geschiedenis, 88 (1975), 562-83; Blockmans and Prevenier, 'Armoede in de Nederlanden', 524-32. For Bruges: P. Van Zeir, 'De inrichting van de Armendissen van de oude Brugse stadsparochies voor 1526', Annales de la Société d'Emulation de Bruges, 97 (1960), 104-53; and M. Galvin, 'Credit and parochial charity in fifteenth-century Bruges', Journal of Medieval History, 28 (2002), 131-54. For Ghent: Nicholas, The Metamorphosis, 41-58; G. De Messemaeker-De Wilde, 'De parochiale armenzorg te Gent in de late Middeleeuwen', Annales de la Société belge d'histoire des hopitaux, 18 (1980), 47-58. 
in their testaments. Sometimes donors specified the people who were to benefit from their donations, but in most cases the lay administrators of the table decided how to distribute the revenues. ${ }^{55}$ The poor tables largely fulfilled a particular social goal: they supported impoverished, but 'respectable' men and women - and not, for example, poor vagrants. Those who received assistance from the seven poor tables in Bruges were householders and wage workers with insufficient income to provide for all of their own needs. These institutions were fairly selective in offering aid to the poor; they gave regular assistance to about 180 paupers, representing perhaps 700 to 900 people (assuming that paupers were heads of households) in a city with a population of perhaps 40,000 (about 2 per cent). This kind of assistance was not large scale, but it was nevertheless structural for a specific, targeted group of paupers. ${ }^{56}$ The poor tables distributed food, made small loans and buried the poor, but the care for the 'shame-faced house-poor' was their primary duty. The purchasers of annuity rents for the poor tables in Bruges, for example, were members of the middle class, or even of the urban elite. ${ }^{57}$ Thus, when they granted aid, the poor tables selected relatively 'wealthy' poor people who needed assistance at a certain point in their lives (for 'critical life situations') ${ }^{58}$ In addition, we have to note that social standing was just as important a criterion as misfortune for assistance from the poor table, because credit extended had to be paid back. The specific social goal of the poor tables makes sense in light of the social composition of their administrations. In Bruges and Ghent, the governors of the poor tables were appointed by the city council, who were wealthy merchants, landholders and representatives of the urban guilds. ${ }^{59}$ Mostly, politicians held an office in the administration of a poor table in between periods of office as alderman or governor of a craft guild, or after the completion of their political career. The narrowness of the social spectrum of poor table beneficiaries therefore resulted from the social and political background of its benefactors and administrators.

The same conclusion can be drawn from an analysis of the poor relief programmes of the craft guilds. From the outset, mutual aid for and by craftsmen figured among the craft guilds' main responsibilities in Ghent

55 G. Maréchal, 'Het openbaar initiatief van de gemeenten in het vlak van de openbare onderstand in het noorden van het land tijdens het Ancien Régime', in Het openbaar initiatief, 298-9.

56 Galvin, 'Credit and parochial charity', 132. In Louvain (Brabant) only welghebornen ('wellborn inhabitants') benefited from the distribution of goods by the tables (Maréchal, 'Het openbaar initiatief', 514).

57 Galvin, 'Credit and parochial charity', 151-2.

${ }_{58}$ M. Anderson, Family Structure in Nineteenth-Century Lancashire (Cambridge, 1971), 136.

${ }^{59}$ For Ghent: M. Boone, Gent en de Bourgondische hertogen ca. 1384 - ca. 1453: een sociaalpolitieke studie van een staatsvormingsproces (Brussels, 1990), 98-102; for Bruges: Haemers, For the Common Good, 185-7. 
and Bruges. ${ }^{60}$ Craft guilds offered a solution for the unpredictable risks and lack of financial reserves of artisans (who supported themselves through manual labour). As collectives of craftsmen they provided their members, and in some cases the wives and children of their members, with a social support network dispensing aid in goods or money. From their origins in the thirteenth and the fourteenth centuries, urban craft guilds in Bruges and Ghent started several poor relief 'boxes' (bussen), with elaborate regulations and designated officials, funded by a compulsory tax (busghelde) on the members of the craft guild and larger donations from wealthier artisans. ${ }^{61}$ The craftsmen were thus collectively responsible for the risks to each individual member of the guild. Several craft guilds in Ghent and Bruges, such as the weavers' and fullers' guilds in both cities, established hospitals for the infirm (godshuus). These institutions were financed by charitable gifts and the real estate holdings of the hospital - comparable to the revenue sources of the 'poor tables'. ${ }^{62}$ This institutionalized solidarity provided needy craftsmen, usually sick, widowed or old, with various benefits, including financial support for the funerals of deceased members. But, as was common in this corporate society, only guild members were allowed to enjoy these services. The 1291 privilege of the porters (the pijnders) of Bruges, for example, stipulates that each member (and only members) would receive a replacement income of $0.5 \mathrm{~d}$.gr.Fl. from the guild administration if he fell ill. ${ }^{63}$ The Ghent hospitals of the weavers' and fullers' guilds only accepted craftsmen as clients, as was also the case for the Bruges guild hospitals. ${ }^{64}$ The craft guilds extended their activities beyond those of a purely economic trade organization. As they were crucial for the establishment and control of social relations and social networks in the cities and for the development of group solidarity and collective identity, they had a very developed social security system. ${ }^{65}$ However, this 'public service' saw its 'public' only within the guild itself.

${ }^{60}$ S. Bos, 'A tradition of giving and receiving: mutual aid within the guild system', in Prak et al. (eds.), Craft Guilds, 174-93; for Bruges: E. Huys, Duizend jaar mutualiteit bij de Vlaamsche Gilden (Kortrijk, 1926); for Ghent: A.-M. De Vocht, 'Het Gentse antwoord op de armoede: de sociale instellingen van wevers en volders te Gent in de late Middeleeuwen', Annales de la Société belge d'histoire des hôpitaux, 19 (1981), 3-32.

61 See for example Huys, Duizend jaar mutualiteit, 162-4; G. Maréchal, 'Armen en ziekenzorg in de Zuidelijke Nederlanden', in Algemene Geschiedenis der Nederlanden (Haarlem, 1982), 277.

62 De Vocht, 'Het Gentse antwoord', 15-16.

63 Huys, Duizend jaar mutualiteit, 147.

${ }^{64}$ De Vocht, 'Het Gentse antwoord', 15; J. Smith, Through the Eye of the Needle: Charity and Charitable Institutions in Medieval Ghent, 1150-1400 (Philadelphia, 1976), 43; J. Huyttens, Recherches sur les corporations gantoises, notamment sur celles des tisserands et des foulons, leur organisation civile, religieuse, militaire et commerciale (Ghent, 1861), 99-102; G. Maréchal, De sociale en politieke gebondenheid van het Brugse hospitaalwezen in de Middeleeuwen (Kortrijk, 1978), 293-4; P. Van Zeir, 'De armenzorg te Brugge', Biekorf, 61 (1960), 367-8; C. Lis and H. Soly, 'Craft guilds in comparative perspective: the Northern and Southern Netherlands, a survey', in Prak et al. (eds.), Craft Guilds, 22-3.

65 Stabel, 'Guilds in late medieval Flanders', 187-8. 
The fifth player in the 'poor relief market' was the wealthy citizen. Not only did the urban elite of Ghent and Bruges patronize the poor tables of their native city, some wealthy elites also founded hospitals in town. These institutions provided welfare facilities to the entire community of citizens, and therefore we can label them as true public services (see the introduction). In Ghent prosperous merchant and landholder families established several hospitals, such as the Alijnshospitaal and the Wenemaershospitaal. ${ }^{66}$ In Bruges, nine similar institutions were founded by rich merchants during the high middle ages for charitable and religious reasons. A close examination of the 'clients' of these lay hospitals, leper houses, mental institutions and travellers' hostels demonstrates that entrance to these institutions was restricted to the needy inhabitants. And not just any poor, but relatively wealthy people who had suffered misfortune or long illness were taken into these institutions ${ }^{67}$ Although most of the hospitals took in genuine paupers in need of healthcare when they were founded in the twelfth or thirteenth century, only uppermiddle-class or elite people were allowed into those institutions in the late middle ages, as was the general pattern in late medieval Europe. ${ }^{68}$ Again, this is not surprising, since both the donors and the governors of the hospitals in Bruges came from the city's wealthy elite. ${ }^{69}$ Also in fifteenth-century Ghent, political control by wealthy governors led to very selective admissions to lay hospitals. ${ }^{70}$

In Ghent and Bruges, institutions for mental and physical health care were also established by the city itself, such as the 'Rijke Gasthuis' leprosarium and St John's mental asylum in Ghent and the 'Dulhuis' asylum and 'Heilige Geesthuis' in Bruges. ${ }^{71}$ Both cities also provided poor relief for their inhabitants. The urban administration distributed some aid on a constant basis, and more in times of food shortage. They distributed corn, bread, peat and occasionally meat to the needy. In Ghent, for example, the city council spent an average of 2.1 per cent of its total budget on social services during the fifteenth century (Table 1). A large share of these funds were handed over to ecclesiastical institutions. Most of the remainder was usually spent on wine and peat distributions, which seems a somewhat odd choice for an efficient poor relief service. As with the ducal charity distributions, it seems that the poor relief provided by the city was not a structurally efficient way of meeting the existing demand for relief. Moreover, a stipulation of the so-called Ghent 'restriction' of 1468 makes it clear that the small amount of charity provided by the city did not

66 Boone, Gent en de Bourgondische hertogen, 149-51; J. Haemers, 'Alijn (Simon)', Nationaal Biografisch Woordenboek, 18 (2007), 8-11; L. Elaut, Het leven van de Gentse ziekenhuizen vanaf hun ontstaan tot op heden (Ghent, 1976).

67 Maréchal, De sociale en politieke gebondenheid, 292-3, 304-5.

${ }^{68}$ Mollat, Les pauvres au Moyen Âge, 316-28.

${ }^{69}$ Maréchal, De sociale en politieke gebondenheid, 295-8.

70 Boone, Gent en de Bourgondische hertogen, 140-50.

71 Ibid., 143-4; Maréchal, De sociale en politieke gebondenheid, 41, 52. 
always end up in the right hands. The restriction was a reform programme developed by the ducal administration, in reaction to complaints about corruption and abuse within the Ghent town magistracy, which had been voiced during the insurrection of 1467 . One of the stipulations of the restriction was the limitation of the annual spending on poor relief, with the specific condition that from now on alms should only be distributed to the poor. ${ }^{72}$ The text clearly suggests that large distributions had been made to people who did not in fact need them. Consequently, it is difficult to explain the motivation of the aldermen when they inadequately supported needy inhabitants. Probably, the reasons were diverse. Politicians were probably at least partially inspired by a concern for their own selfpreservation. By distributing goods they were trying to sustain a kind of 'moral economy' of the poor, as E.P. Thompson described it. ${ }^{73}$ Especially in times of political crisis, urban governments tried to prove that they successfully provided public services, made available public services in order to legitimize their politics. ${ }^{74}$ Nevertheless, we cannot exclude the possibility that the politicians also felt sincere pity for disabled and unfortunate people. However, during the late fifteenth century, there was a pronounced tendency towards labour regulation in poor relief - a tendency that would grow in the following centuries. ${ }^{75}$

In short, the evidence suggests that every corporate body in medieval Ghent and Bruges had its own system of poor relief and health care. Craft guilds provided a kind of social security for their members in times of need. Urban elites, wealthy citizens and the middle class who did not belong to a craft guild received poor relief and health care from private hospitals if they became impoverished due to unfortunate circumstances. Some of the urban hospitals were financed with city funds, but a certain social and political selection of the patients took place in those hospitals, just as it did in hospitals founded by private or ecclesiastical initiatives. While these exclusive institutions provided services for the wealthy segment of the urban population, the 'poor tables' served the less prosperous inhabitants. But again, the 'clientele' of these institutions was targeted twice. For juridical reasons only inhabitants of the parish who had rights as citizens were allowed to receive services from the 'table' - a distinction between craftsmen and other citizens was not made. However, a second, sociopolitical filtering process preceded the final decision to help individuals, because the 'tables' principally provided members of the elite and the

72 V. Fris (ed.), 'La restriction de Gand (13 juillet 1468)', Bulletijn der maatschappij van geschieden oudheidkunde te Gent, 31 (1923), 81; Ryckbosch, Tussen Gavere en Cadzand, 60-91.

73 By 'moral economy' we point to the social norm which predicates that rulers have to shape necessary conditions for food supply in the city (E.P. Thompson, 'The moral economy of the English crowd in the eighteenth century', Past and Present, 51 (1971), 76-136).

74 See, for example, the charity of Ghent rebel leaders of 1452 who distributed goods among their followers (Haemers, De Gentse opstand, 256-7, 361-2).

75 M. Prak, 'The carrot and the stick: social control and poor relief in the Dutch Republic, sixteenth to eighteenth centuries', in H. Schilling (ed.), Institutionen, Instrumente und Akteure sozialer Kontrolle und Disziplinierung im frühneuzeitlichen Europa (Frankfurt, 1999), 149-66. 
middle class with poor relief and health care. Services for the poor and needy provided by municipal institutions in the medieval city therefore seem to have been very restrictive. Poor relief by the count and generous clerical institutions can be interpreted in the same way. Presumably the gifts by the count and the abbeys were not arbitrary, but also socially or politically targeted - although there is insufficient detailed evidence to prove this hypothesis. ${ }^{76}$ Nevertheless it is clear that citizenship rights, religious motivations, political selection and membership in a corporation were important criteria for those who wished to enjoy public services in late medieval society. The public assisted by these services was certainly not the general public, but a targeted public.

\section{Conclusion}

The provision of legal and personal security, order, infrastructure, health care and poor relief in fifteenth-century Ghent and Bruges can be regarded as 'public services'. However, in contrast to the presumptions regarding this notion, following the political rhetoric of nineteenth-century theorists, the public services in the medieval city were not provided for the common good of every citizen. Nor were the municipal authorities the only providers of public facilities. For each service mentioned above, there were several different institutional providers, most often the town aldermen, ecclesiastical institutions and craft guilds, but sometimes also the emerging central state and the wealthiest urbanites. The medieval city was composed of different corporate bodies, each of which provided specific services. No single institution achieved, or even attempted to achieve, a monopoly on the supply of public services. Medieval public services were multilayered in another way as well. The fragmentation of supply led to an equally fragmented demand, and perhaps that was the intention all along. Each institution targeted its services to a specific layer of society, rather than to all inhabitants of the city. Medieval public services were not only multi-layered, but also restrictive. Legal restrictions, social boundaries and tax burdens determined which services an individual could use. The boundaries around groups which were eligible for public services were strict and only overlapped for specific social groups. While the master craftsmen benefited both from the services available for citizens as well as from those available to craft guild members, the immigrant day labourer was not entitled to any at all. In short, urban public services were not in the interest of all citizens.

76 The habit of the governors of the 'Sint-Jacobshuis' in Ghent (a house for pilgrims) of selecting poor for a meal on holidays by distributing lead signs in the Fishmarket, indicates that a certain social selection in poor relief existed (S. Meersseman, 'Het "Sente Jacopshuus up Nieuwland" te Gent. Godshuis of politiek instelling? (ca. 1257-1540)', HMGOG, 45 (1991), 10). 
This paper has little to say about the effectiveness of late medieval public services in improving the living conditions of the urban population. Because the demand for public services is difficult to reconstruct, the historian is forced to concentrate on the supply side. There are some indications, however, that the services provided by the city magistrates left much to be desired. For instance, as poverty and high grain prices increased at the end of the fifteenth century, Ghent and Bruges made only tiny increases in their spending for poor relief. Neither do the municipal infrastructure projects nor the judicial practices of the aldermen suggest that the demand for public services was optimally met. Although the city government seems to have gained some political legitimacy from providing public services, its existence did not depend on its effectiveness in providing those services - as is expected of twenty-first-century 'welfare states'. Providing services for the larger community instead of just a targeted group within urban society (demarcated by social, legal and fiscal boundaries) was not a priority for late medieval urban politicians. Rather, the magistrates of Ghent and Bruges intended to protect the interests of specific elite groups, for whom the provision of public services served a number of economic goals as well as legitimatizing their political authority. ${ }^{77}$

77 Although we agree with Steven Epstein that Sheilagh Ogilvie simplifies the role of the craft guilds and economic institutions in the history of medieval economy, we were inspired by her worries about the tendency to explain institutions as an efficient and beneficial response to historical needs. For 'public services' in the medieval city did not arise and survive because they made urban government more efficient, they were set up for the aforementioned goals. See S. Ogilvie, "Whatever is, is right"? Economic institutions in pre-industrial Europe', Economic History Review, 60 (2007), 649-84, and the reply of S. Epstein, 'Craft guilds in the pre-modern economy: a discussion', Economic History Review, 61 (2008), 155-74. 